\title{
サルコイドーシスにおける診断，免疫反応の解析，転帰，臨床病型の 解析
}

\section{四十坊典晴}

\section{【要旨】}

サルコイドーシスの臨床経過はきわめて多様な幅がある．診断時においても眼病変のみで診断に難渋する場合 もある．豊富な症例を有する JR札幌病院の症例を中心に本症の 1 ．診断， 2 ．免疫反応の解析， 3 ．転帰，臨床 病型の解析を行った５16例の組織診断群を用い，各種検查所見（血清 ACE，血清リゾチーム，血清免疫グロブ リン $\mathrm{G}$ ，ツベルクリン反応，気管支肺胞洗浄（BAL）検査，ガリウム・シンチグラフィー）を診断時に行い，胸 部X線病期ごとの異常の陽性率を解析した，肺局所の免疫応答に関してBAL液細胞を用い，Th1反応における Interleukin-12（IL-12）とIL-18の重要性および転帰におけるClara cell 10-kDa蛋白質の重要性に関して検討を行っ た. 臨床型に関して多施設共同研究（JR札幌病院，JR東京総合病院，日本赤十字社医療センターと京都大学）と して，5年以上経過観察したサルコイドーシス症例を臨床型の判定に関するWASOG作業部会における取り決め に基づき分類し，検討した.

[日サ会誌 2010; 30: 5-8]

キーワード：サルコイドーシス，診断，インターロインキン-18，クララ細胞（CC10）蛋白質，転帰

\section{Diagnosis and Analysis of Immunological Response and Outcome According to Clinical Phenotypes in Sarcoidosis}

\author{
Noriharu Shijubo
}

Keywords: sarcoidosis, diagnosis, interleukin-18, Clara cell 10-kDa protein, outcome

\section{はじめに}

サルコイドーシスの臨床経過はきわめて多様な幅が ある。目本においては診断時に眼病変のみで胸郭内病 変を認めない症例も多く存在し, 診断に苦慮する場合 が多い ${ }^{1,2}$. 自然経過としては多くは発症発見から 2 年 以内に自然に寛解するが, 一方では, 数年にわたって 慢性化していき，この中から治療が必要な場合がでて くる. 臨床経過に基づいて本症は慢性型とか急性型 とかに判定されるわけである。従来は発症発見から 2 年以内に治療薬としての副腎皮質ステロイドホルモン 薬（ステロイド）を減量し, 中止できるかどうかを判 定基準にしてきたが, 減量中止した症例から再発がみ
られる率も $40 \%$ 程度と報告されている。 さらに，欧 米の報告でも, 重症度には人種差があり, 経口ステロ イドの治療導入率もかなり幅が見られる。日本におい ては肺病変が欧米に比べ重症化しにくいとされてきた が，長期観察の報告は少なく，肺病変の重症化，難治 化に関しては不明な点が多く残されている，著者は豊 富なJR札幌病院（旧札幌鉄道病院）の症例を中心に 本症の臨床的，基礎的解析を行ってきた．今回はその 内容を 1 . 診断基準の検討, 2 . 免疫反応の解析, 3 . 転帰, 臨床病型の解析（多施設共同研究）に分けて報 告する. 


\section{I . 診断基準の検討}

診断に関して, 組織学的に類上皮細胞肉芽腫を証明 したサルコイドーシス 516 例（病期 $0 ， 150$ 例 ; 病期 1,256 例 ; 病期 2,86 例 ; 病期 3，24例）を用いて, 各種検查所見（血清ACE，血清リゾチーム，血清免 疫グロブリン $\mathrm{G}(\mathrm{IgG})$, ツベルクリン反応（ツ反）, 気管支肺胞洗浄 (BAL) 検査，ガリウム・シンチグ ラフィー）を診断時に行い，異常の陽性率を解析し た ${ }^{2)}$. 非喫煙者が232例で契煙者が284例であった，眼 病変は516例中 375 例 $(72.7 \%$ ）に認められ, 病期 0 で は137例 $(91.3 \%)$, 病期 1 では 174 例 $(68.0 \%)$, 病期 2 では 53 例 $(61.6 \%)$, 病期 3 では 11 例 $(45.8 \%)$ で あった. 当院で採用している検查值の正常範囲に関し ては血清 $\mathrm{ACE}$ では $14.1 \sim 23.7 \mathrm{U} / \mathrm{mL} 37^{\circ} \mathrm{C}$ (以下 $37^{\circ} \mathrm{C}$ を省略）で，血清リゾチームでは $4.2 \sim 11.5 \mu \mathrm{g} / \mathrm{mL}$ で血清IgGでは $870 \sim 1,700 \mathrm{mg} / \mathrm{dL}$ であり，それぞ れのカットオフ值を $23.7 \mathrm{U} / \mathrm{mL}, 11.5 \mu \mathrm{g} / \mathrm{mL}, 1,700$ $\mathrm{mg} / \mathrm{dL}$ とした. ツ反は長径が $9 \mathrm{~mm}$ 以下の場合にサ ルコイドーシスに合致した所見とし，陽性とした。 BAL所見はリンパ球比率とCD4/CD8比に関し, 解析 を行った。喫煙者 284 例中 6 例でリンパ球比率が低く CD4/CD8比は解析できなかった. CD4/CD8比の陽性 率の検討では解析できなかった症例は陰性とした。ガ リウムシンチは縦隔および肺野への集積の有無を検討 した。

516例の血清 ACE, 血清リゾチーム, 血清IgGの平 均值は $24.9 \mathrm{U} / \mathrm{mL}, 13.3 \mu \mathrm{g} / \mathrm{mL}, 1,380 \mathrm{mg} / \mathrm{dL}$ であり, 全体の陽性率はそれぞれ $49.8 \%, 51.7 \%, 13.8 \%$ であっ た. 血清ACEと血清リゾチームに比較し, 血清 IgG の陽性率は極めて低かった。病期 0 では血清 ACEと 血清リゾチームの平均值は $20.2 \mathrm{U} / \mathrm{mL}$ と $9.7 \mu \mathrm{g} / \mathrm{mL}$ で あり，陽性率はそれぞれ $30.0 \%$ と $24.0 \%$ であり，他の 病期に比較し，陽性率が有意に低かった。病期 3 期の 血清 ACEの平均は $23.7 \mathrm{U} / \mathrm{mL}$ で陽性率は $37.5 \%$ で病 期 1 と病期 2 に比較し有意に低值であった。

516例のサルコイドーシス患者のツ反の陰性は $69.2 \%$ に認められ, 病期 0 , 病期 1 , 病期 2 , 病期 3 ではそれぞれ $64.0 \%, 68.8 \%, 77.4 \%, 87.5 \%$ であ り, 年齢 10 歳ごとの解析でもほとんど差は認められ なかった。

BAL所見は非喫煙者と契煙者に分け，解析を行っ た. 非喫煙者232例のリンパ球比率と CD4/CD8比 の平均は $44.0 \%$ と $6.02 て ゙$, 喫煙者 284 例のリンパ球

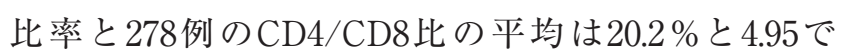
あり, 非喫煙者は喫煙者に比較し, リンパ球比率と
$\mathrm{CD} 4 / \mathrm{CD} 8$ 比は有意に高值であった。病期 0 , 病期 1 , 病期 2 , 病期 3 の非契煙者群のリンパ球比率はそれ ぞれ $36.8 \%, 47.2 \%, 51.0 \%, 47.1 \%$ あ゙り，病期 0, 病期 1 , 病期 2 , 病期 3 の非契煙者群の CD4/CD8比

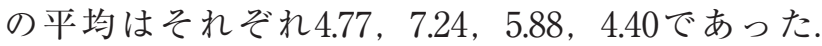
病期 0 , 病期 1 , 病期 2 , 病期 3 の契煙者群のリンパ 球比率はそれぞれ $16.3 \%, 22.0 \%, 20.7 \%, 17.1 \%$ で あり, 病期 0 , 病期 1 , 病期 2 , 病期 3 の契煙者群の $\mathrm{CD} 4 / \mathrm{CD} 8$ 比の平均はそれぞれ $5.29,4.93,4.76,4.31$ であった。

非契煙者ではカットオフ值を $30 \%$ にした場合に全 体では $76.7 \%$ が陽性であり, 病期 0 , 病期 1 , 病期 2 , 病期 3 の非喫煙者群のリンパ球比率の陽性率はそれぞ れ $65.1 \% ， 80.6 \% ， 96.6 \% ， 75.0 \%$ あった。契煙者 ではカットオフ值を $10 \%$ にした場合に全体では $75.3 \%$ が陽性であり, 病期 0 , 病期 1 , 病期 2 , 病期 3 の 喫煙者群のリンパ球比率の陽性率はそれぞれ $70.1 \%$, $75.7 \%$ ， 84.4\%，58.3\%であった。リンパ球比率のカッ トオフ值は非契煙者では $30 \%$ ，契煙者では $10 \%$ が妥 当と考えられ，その場合では全体では $76.0 \%$ が陽性 で, 病期 0 , 病期 1 , 病期 2 , 病期 3 ではそれぞれ 67.3\%，77.7\%，88.4\%，66.7\%が陽性であった。

$\mathrm{CD} 4 / \mathrm{CD} 8$ 比のカットオフ值は従来から報告されて いる $3.5 て ゙$ 解析を行った。喫煙者では $63.4 \%$ が陽性で, 喫煙者では $55.6 \%$ 陽性であり，全体では $59.1 \%$ \% 陽 性であった。病期 0 , 病期 1 , 病期 2 , 病期 3 の非 喫煙者群のCD4/CD8比の陽性率はそれぞれ $44.6 \%$, $75.9 \%, 75.9 \%, 50.0 \%$ で, 病期 0, 病期 1 , 病期 2 , 病期 3 の喫煙者群のCD4/CD8比の陽性率はそれぞ れ $55.2 \% ， 58.1 \% ， 56.1 \% ， 25.0 \%$ であり，全体では 病期 0 , 病期 1, 病期 2, 病期 3 でそれぞれ $49.7 \%$, $65.6 \% ， 62.8 \% ， 37.5 \%$ が陽性であった。

リンパ球比率とCD4/CD8比がともに陽性である割 合は非契煙者では $54.3 \%$ で，契煙者では $47.5 \%$ であ り，全体では $50.6 \%$ が陽性であった。病期 0 , 病期 1 , 病期 2 , 病期 3 の非喫煙者群でリンパ球比率とCD4/ CD8比がともに陽性である割合はそれぞれ $38.6 \%$ ， $62.0 \%, 75.9 \%, 41.6 \%$ で, 病期 0 , 病期 1 , 病期 2 , 病期 3 の喫煙者群でリンパ球比率と CD4/CD8比が陽 性の割合はそれぞれ $44.8 \%, 50.0 \% ， 49.1 \% ， 25.0 \%$ であり, 全体では病期 0 , 病期 1 , 病期 2 , 病期 3 で それぞれ $41.3 \% ， 55.1 \% ， 58.1 \% ， 33.3 \%$ が陽性であっ た。

リンパ球比率と $\mathrm{CD} 4 / \mathrm{CD} 8$ 比の少なくとも 1 つが陽 性である割合は非喫煙者では $88.8 \%$ で，契煙者では 
$83.8 \%$ であり，全体では $86.0 \%$ が陽性であった。病期 0 , 病期 1 , 病期 2 , 病期 3 の非喫煙者群でリンパ球 比率と CD4/CD8比が少なくとも 1 つが陽性である割 合はそれぞれ $78.3 \%, 94.4 \%, 96.6 \%, 91.7 \%$ で, 病 期 0 , 病期 1 , 病期 2 , 病期 3 の喫煙者群でリンパ 球比率と CD 4/CD8比の少なくとも 1 つが陽性の割合 はそれぞれ $80.6 \%, 84.5 \%, 91.2 \%, 58.3 \%$ ありり 全体では病期 0 , 病期 1 , 病期 2 , 病期 3 で $79.3 \%$, $88.7 \%$ ，93.0\%，75.0\%が陽性であった。どちらか 1 つが陽性である場合にBAL検査陽性として検討を 行った.

ガリウム・シンチグラフィーでの縦隔リンパ節への 集積艺進が認められた割合は $80.2 \%$ であり, 肺野への 集積立進が認められた割合は $12.0 \%$ であり, 少なくと もどちらか一方に集積立進が認められる割合は $82.2 \%$ であった. 病期 0 , 病期 1 , 病期 2 , 病期 3 で縦隔 リンパ節への集積立進が認められた割合はそれぞれ $55.3 \%, 94.9 \%, 91.9 \%, 37.5 \%$ であり, 病期 0, 病 期 1 , 病期 2 , 病期 3 で肺野への集積立進が認められ た割合はそれぞれ $2.7 \% ， 6.6 \% ， 36.0 \%, 41.7 \%$ あっす た. 病期 0 , 病期 1 , 病期 2 , 病期 3 で少なくとも どちらか一方に集積立進が認められる割合はそれぞれ $56.7 \%$ ，95.7\%，92.9\%，62.5\%であった. 少なくと もどちらか 1 つに集積立進が認められる場合にガリウ ム・シンチグラフィー検査陽性として検討を行った。

6 つの検査項目についてサルコイドーシスに合致 し，陽性とした検査所見があった場合にはスコアーを 1 とし, 合致しない場合には 0 として解析を行った. 516例でのスコアーの平均は3.53であり, 病期 0 , 病 期 1 , 病期 2 , 病期 3 ではそれぞれ平均は $2.67,3.81$, 4.22 ，3.42であった。病期 0 では各種検査の合計スコ アー值が極めて低かった。

\section{II . 免疫反応の解析}

サルコイドーシスにおいて, 肺局所病変を反映する と考えられるBAL液細胞を用いて種々と検討を加え た. 炎症性サイトカインである interferon- $\gamma$ (IFN- $\gamma$ ) やtumor necrosis factor- $\alpha$ により誘導させる接着分子 intercellular adhesion molecule-1 (ICAM-1) が病変 局所のリンパ球上で発現が立進し, 可溶性ICAM-1が サルコイドーシスにおいて血中およびBAL液中で増 加していることを明らかにした ${ }^{3,4)}$.

サルコイドーシスのBAL液細胞ではTh1細胞由 来サイトカインであるinterleukin-2（IL-2）とIFN$\gamma$ mRNAが健常者と比較して, 有意に増加し, IL-4
mRNAに変化がないことを明らかにした5)。また， IFN- $\gamma$ 産生誘導に重要なサイトカインであるIL-12 mRNA発現を認めた場合には認めなかった症例に比 較して有意にIFN- $\gamma$ mRNAが増加していた。また， IFN- $\gamma$ 産生誘導因子としてクローニングされたIL-18 に関して臨床的意義を検討し，サルコイドーシスにお いて血中IL-18は有意に増加し，また，BAL液中IL-18 も有意に増加することを明らかにした6)。さらに， BAL液中でIL-12p40が増加し，BAL液細胞をLPSで 刺激すると有意にIFN- $\gamma$, IL-12p70, IL-18が増加す ることを明らかにし，サルコイドーシスBAL液細胞 をIL-12 と IL-18で共刺激することにより著しいIFN- $\gamma$ 産生立進が生じ，LPS刺激した場合にはIL-12および IL-18中和抗体でIFN- $\gamma$ 産生は約 $70 \%$ 抑制されること を示した ${ }^{7)}$ 。サルコイドーシス症例において IL-12p40 が増加すること ${ }^{8)}$, Th1反応制御における免疫調節剂 の有用性も検討した ${ }^{9)}$. 血中サルコイドーシスの病変 局所でTh1反応が充進していることを明らかにした。

Clara cell 10-kDa 蛋白質（以下CC10）は細気管支 領域の無線毛上皮細胞（Clara細胞）より主に産生分 泌される蛋白質であり，抗炎症蛋白として機能する 10). サルコイドーシスのBAL液中 CC10值は健常者 とは有意差を認めないが，サルコイドーシスの血中 CC10值が有意に高值になることを明らかにし，さら に，予後良好群において予後不良群と比較し，血中お よびBAL液中で有意に高值であることを明らかにし た ${ }^{11)}$. CC10遺伝子多型G38Aに関して子後因子であ る可能性を検討した ${ }^{12)}$. 38Aアレルがサルコイドーシ スで健常者に比較し有意に多く, さらに増悪群におい て38Aアレルの増加を認め, サルコイドーシスにおい て $\mathrm{A} / \mathrm{A}$ 群で $\mathrm{G} / \mathrm{G}$ 群と $\mathrm{G} / \mathrm{A}$ 群に比較し血中およびBAL 液で CC10值の有意な低下を認めた。 また，IFN- $\gamma$ 存 在下で38 A アレルでは38Gアレルに比較し，プロモー ター活性が有意に低下していた。

サルコドーシス患者においてCC10遺伝子多型G38A がCC10産生に関与し，増悪との関連を明らかにした。

\section{III. 転帰, 臨床病型の解析}

サルコイドーシスの臨床型に関して多施設共同研究 （JR札棍病院, JR東京総合病院, 日本赤十字社（以下 日赤）医療センターと京都大学）として，5年以上 経過観察したサルコイドーシス症例を寛解（完全寛 解, 部分寛解), 残存, 慢性化, 治療中, 悪化という 観点から 9 型 [1. 寛解・未治療，2．寛解・過去治 療有，3. 部分寛解・未治療，4. 部分寛解・過去治 
療有, 5. 残存・未治療, 6. 残存・過去治療有, 現 在治療中：無症状 (7), 有症状で過去 1 年以内悪化 なし（8）と悪化群（9）に分類し検討した ${ }^{13)}$. JR 札幌病院, JR東京総合病院, 日赤医療センター, 京 都大学の 4 施設の検討した症例数はそれぞれ 74 例, 49 例，36例，55例であった．JR札棍病院とJR東京総合 病院では過去の一定期間に診断された連続症例が集 積検討された. 日赤医療センターと京都大学では一定 期間に受診し 5 年以上経過観察された症例を集積検討 された. 病院ごとの診断時の胸部 X線病期ではJR札 棍病院とJR東京総合病院では病期 0 と病期 1 の比率 が高く, 日赤医療センターでは病期 2 と病期 3 の比率 が高く, 京都大学では病期 2 が多かった.JR札幌病 院では病期 3 を認めなかった。これらの違いは検討症 例の選択方法による可能性が高い. 眼病変の合併率は $57 \%$ から $86 \%$ であった。皮膚病変の合併率は 7 \%か ら $39 \%$ で, JR札幌病院が $7 \%$ と低率であった. JR札 幌病院では 9 例, JR東京総合病院では 3 例が 5 年以 内に外来を受診しなくなり，5年以上の経過を追うこ とができないが，札幌鉄道病院の場合はいずれも未治 療で 2 例が 1 年以内の経過観察で 7 例が 3 年まで経過 観察をしており，3 年経過を観察された症例 7 例では すべて病変は消失していた。

4 施設の成績は完全宽解が $2 \%$ から $44 \%$, 部分寞 解が $3 \%$ から $15 \%$, 持続が $3 \%$ から $28 \%$, 現在治療 中は $25 \%$ から $60 \%$ であった. 治療は経口ステロイド, 局所ステロイド（吸入ステロイドと点眼ステロイド）, 免疫抑制剤, 抗生剂, 抗うつ剤, NSAIDsが含まれ, 現在治療中の内容を経口ステロイド剤に限定した場合

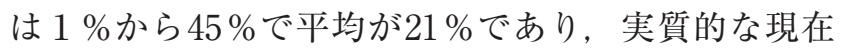
治療中を反映した結果であることを明らかにした。

\section{おわりに}

$\mathrm{JR}$ 札幌病院の豊富な症例の臨床的, 基礎的検討か らサルコイドーシスに拀ける診断, 免疫反応の解析, 転帰, 臨床病型の解析に関して, 報告した。

本稿は第29回日本サルコイドーシス／肉芽腫性疾 患学会総会に扔ける「千葉保之・本間日臣記念賞」の 受賞講演の内容をまとめたものである.

\section{引用文献}

1 ) 平賀洋明：サルコイドーシスの臨床. 日サ会誌 2003; 23: 33-41.

2 ) 四十坊典晴, 伊藤峰幸, 市村志保, 他 : 類上皮細胞肉芽腫 を証明したサルコイドーシス 516 例における各種検査所見
の解析. 日サ会誌 2007; 27: 29-36.

3 ) Shijubo N, Imai K, Shigehara K, et al: Soluble intercellular adhesion molecule-1 (ICAM-1) in sera and bronchoalveolar lavage fluids of patients with idiopathic pulmonary fibrosis and pulmonary sarcoidosis. Clin Exp Immunol 1994; 95: 156-161.

4 ) Shijubo N, Imai K, Shigehara K, et al: Circulating soluble intercellular adhesion molecule-1 (ICAM-1) in patients with sarcoidosis. Clin Exp Immunol 1996; 106: 549-554.

5 ) Shigehara K, Shijubo N, Ohmichi M, et al: Enhanced mRNA expression of Th1 cytokines and IL-12 in active pulmonary sarcoidosis. Sarcoidosis Vasc Diffuse Lung Dis 2000; 17: 151-157.

6 ) Shigehara K, Shijubo N, Ohmichi M, et al: Increased levels of interleukin-18 in patients with pulmonary sarcoidosis. Am J Respir Crit Care Med 2000; 162: 1979-1982.

7 ) Shigehara K, Shijubo N, Ohmichi M, et al: IL-12 and IL-18 are increased and stimulate IFN- $\gamma$ production in sarcoid lungs. J Immunol 2001; 166: 642-649.

8 ) Shigehara K, Shijubo N, Ohmichi M, et al: Increased circulating interleukin-12 (IL-12) p40 in pulmonary sarcoidosis. Clin Exp Immunol 2003; 132: 152-157.

9 ) Takahashi R, Shijubo N, Shigehara K, et al: T helper 1 inhibitor TAK-603 inhibits IFN- $\gamma$ and IL-12 production with no effect on IL-18: an observation in sarcoidosis patients. Sarcoidosis Vasc Diffuse Lung Dis 2004; 21: 204-211.

10) Shijubo N, Kawabata I, Sato N, et al: Clinical aspects of Clara cell 10-kDa protein/uteroglobin (secretoglobin 1A1). Curr Pharm Des 2003; 9: 1139-1149.

11) Shijubo N, Itoh Y, Shigehara K, et al: Association of Clara cell $10-\mathrm{kDa}$ protein, spontaneous regression and sarcoidosis. Eur Respir J 2000; 16: 414-419.

12) Ohchi T, Shijubo N, Kawabata I, et al: Polymorphism of Clara cell $10-\mathrm{kD}$ protein gene of sarcoidosis. Am J Respir Crit Care Med 2004; 169: 180-186.

13）四十坊典晴, 生島壮一郎, 山口哲生, 他：臨床所見, 自 然経過および治療反応性に基づくサルコイドーシスの臨 床型. 日サ会誌 2007; 27: 21-28. 